\title{
Screening of free living rhizobacteria associated with wheat rhizosphere for plant growth promoting traits
}

\author{
Adesh Kumar $^{1 *}$, Shambhoo Prasad ${ }^{1}$ and Sushil Kumar Singh ${ }^{2}$ \\ ${ }^{1}$ Department of Plant Molecular Biology and Genetic Engineering, N. D. University of Agriculture and Technology, \\ Kumarganj, Faizabad-224229 (U. P.) India. \\ ${ }^{2}$ Department of Plant Pathology, N. D. University of Agriculture and Technology, Kumarganj, Faizabad-224229 \\ (U. P.) India.
}

Received 16 July, 2013; Accepted 20 February, 2014

\begin{abstract}
The use of plant growth promoting rhizobacteria (PGPR) for the benefits of agriculture is gaining worldwide importance and acceptance and appears to be the trend for the future. PGPR are bio-resources which may be viewed as a novel and potential tool for providing substantial benefits to the agriculture. Plant growth promoting rhizobacteria (PGPR) are known to influence plant growth by various direct or indirect mechanisms. In search of efficient PGPR strains with multiple activities, a total of 58 isolates belonging to Pseudomonas, Azotobacter and Bacillus were isolated from wheat rhizospheric soils collected from various districts of Uttar Pradesh. These rhizospheric isolates were biochemically characterized and screened for their plant growth promoting traits like production of indole acetic acid (IAA), ammonia production, siderophore production, phosphate solubilization, salt tolerance and antibiotic sensitivity test activity. The isolates of Pseudomonas (86.36\%), and Azotobacter (76.13\%) produced IAA, whereas only $\mathbf{3 8 . 0 9 \%}$ of Bacillus isolates were able to produce IAA. Ammonia production was most common trait of Pseudomonas (90.89\%), and Azotobacter (66.43) and Bacillus (76.19\%). Phosphorus solubilization was detected in the isolates of Azotobacter (66.23\%), Pseudomonas (45.35\%), and Bacillus (23.80\%). Siderophore production was exhibited by 9.61 to $20.17 \%$ of isolates. On the basis of multiple plant growth promoting activities eighteen isolates (nine Azotobacter, six Pseudomonas and three Bacillus) were evaluated for quantitative IAA production, antibacterial and salt tolerance. All the Azotobacter isolates were shown to produce higher range $(95.60$ to $175.20 \mu \mathrm{g} / \mathrm{ml})$ of IAA, while Pseudomonas produced (44.40 to $95.60 \mu \mathrm{g} / \mathrm{ml}$ ) IAA. The isolate Bc2 also showed potential of producing high amount of IAA. The isolate Azt5, Azt9, Ps2, Bc2 and Bc3 were found resistant even at $20 \mu \mathrm{g} / \mathrm{ml}$ concentration of tetracycline in the medium. Salt tolerance even at $7 \% \mathrm{NaCl}$ concentration was observed in Azt5, Bc1 and Bc3 isolates. This study has pointed out that few isolates could exhibit PGP traits, which may promote plant growth directly and indirectly.
\end{abstract}

Key words: Plant growth promoting rhizobacteria (PGPR), wheat, indole acetic acid, ammonia, siderophore, P solubilization, salt tolerance, antibacterial activity.

INTRODUCTION

Cereals such as rice, wheat and maize, are the major grains that sustain humanity. Wheat grows in temperate climates and it is staple food for $35 \%$ of the world's population. On the other hand, it provides more calories and proteins in the diet than any other crop (Laegreid et al., 1999). Wheat is one of the major crops cultivated in India and all over the world. Climatic conditions and modern agriculture have been severally modifying and 
polluting the natural environment. The increasing demand for a steady and healthy food supply by a burgeoning human population will require efficient management practices along with controlling disease that reduce crop yield. During last few decades, agricultural production has increased due to the use of high yielding varieties and enhanced consumption of chemicals, which are used both as fertilizers to provide nutrition and as protection agents to control the damage caused by phytopathogens. Excessive use of chemicals and change in traditional cultivation practices has resulted in the deterioration of physical, chemical and biological health of the cultivable soil. Microbial diversity in soil is considered important for maintaining the sustainability of agriculture production systems (Stark et al., 2007). The variability in the performance of Plant Growth Promoting Rhizobacteria may be due to various environmental factors that may affect their growth and exert their effects on plants. The environmental factors include climate, weather conditions, soil characteristics or the composition or activity of the indigenous microbial flora of the soil. To achieve the maximum growth promoting interaction between PGPR and crop plants, it is important to discover how the rhizobacteria exerting their effects on plant and weather, the effects are altered by various environmental factors including the presence of other microorganisms (Bent et al., 2001).

The functions of soil biota are central to decomposition processes and nutrient cycling. Soil is considered a storehouse of microbial activity, though the space occupied by living microorganisms is estimated to be less than $5 \%$ of the total space. Therefore, major microbial activity is confined to the 'hot-spot', that is, rhizosphere. The growth of many microorganisms in the rhizospheric region depends upon the root exudates released by the plants (Bais et al., 2006). Interactions between plant and microbes are intensely studied and especially those that benefit plant growth. PGPRs may benefit the host by causing plant growth promotion or biological disease control. PGPR activity has been reported in strains belonging to several genera such as Azotobacter, Pseudomonas, Azospirillum, Acetobacter, Burkhalderia and Bacillus (Kloepper et al., 1989; Glick 1995; Glick and Bashan, 1997; Rangrajan et al., 2002; Ahmad et al., 2005; Fischer et al., 2007; Joseph et al., 2007; Sachdeva et al., 2009; Agrawal et al., 2011). PGPR can exhibit a variety of characteristics responsible for influencing plant growth. The common traits include production of growth regulators (auxin, gibberellins, ethylene etc), siderophore, ammonia, Phosphorus solubilization, $\mathrm{HCN}$ and antibiotics(Wahyudi et al., 2011; Etesami et al., 2009; Ahmad et al., 2008; Ahmad et al., 2005; Dilfuza, 2005; Valverde et al., 2003). Plant diseases are responsible for annual crop losses at a total value of more than 200 billion (Agrios, 2005). Resistant plants and chemicals are often used to control plant diseases. Resistance does not exist against all diseases and the breeding of resistant plants takes many years. The use of microbes to control diseases, which is a form of biological control, is an environment-friendly approach. The microbe is a natural enemy of the pathogen, and if it produces secondary metabolites, it does so only locally, on or near the plant surface, that is, the site where it should act. In contrast, the majority of molecules of agro-chemicals do not reach the plant at all (Flores et al., 2006). An effective plant growth promoting and biological control strains isolated from one region may not perform in the same way in other soil and climatic conditions (Duffy et al., 1997; Johnson et al., 1998). Isolating of native strain adapted to the environment and their study may contribute to the formulation of inoculants to be used in region crops. The different stages of life cycle of wheat consist of elongation, flowering, fruiting and ripening stages. It is found that rate of roots exudates released by the root of the wheat at flowering stage is higher as compared to other stages, hence greater microbial biota and activity is expected during this stage (Huddedar et al., 2000). Thus, the present study aims to investigate native PGPR free living bacteria, associated with rhizosphere of wheat during flowering stage to evaluate their ability to enhance the growth and yield of wheat under the ecological condition of Uttar Pradesh.

\section{MATERIALS AND METHODS}

\section{Soil sample collection}

Soil samples were collected from the rhizosphere of different wheat growing areas of Uttar Pradesh during the flowering stage. The wheat plants were uprooted from the field and rhizosphere soil was pooled and filled in sterile polythene bags.

\section{Isolation and characterization of plant growth promoting rhizobacteria}

\begin{abstract}
All the strains of Pseudomonas, Azotobacter and Bacillus were isolated from the rhizosphere of wheat grown in various locations in Uttar Pradesh, India. The Pseudomonas strains were isolated on Kings $\mathrm{B}$ medium containing (Protease peptone $20 \mathrm{~g}$, Glycerol 10 $\mathrm{ml}, \mathrm{K}_{2} \mathrm{HPO}_{4} 1.5 \mathrm{~g} \mathrm{MgSO}_{4} .7 \mathrm{H}_{2} \mathrm{O} 1.5 \mathrm{~g}$, Agar $18 \mathrm{~g}, \mathrm{pH}$ 7.2) per litre of distilled water; whereas Azotobacter on Jensen's medium containing (Sucrose $20 \mathrm{~g}, \mathrm{~K}_{2} \mathrm{HPO}_{4} 1 \mathrm{~g}, \mathrm{MgSO}_{4} 0.5 \mathrm{~g}, \mathrm{NaCl} 0.5$, $\mathrm{Na}_{2} \mathrm{MoO}_{4} 0.001 \mathrm{~g}, \mathrm{FeSO}_{4} 0.01 \mathrm{~g}, \mathrm{CaCO}_{3} 2 \mathrm{~g}$, Agar $18 \mathrm{~g}, \mathrm{pH} 7.0$ ) per litre of distilled water, and Bacillus on the nutrient agar containing 5 $\mathrm{g}$ peptone, $3 \mathrm{~g}$ beef extract and $18 \mathrm{~g}$ Agar per liter of distilled water. The plates were incubated at $30^{\circ} \mathrm{C}$ for $24 \mathrm{~h}$. After incubation, plates were observed for different isolates based on morphological
\end{abstract}


features. Morphologically variable colonies picked up and purified on respective media plates. The pure cultures of isolates were made and preserved on the respective media slants. The total fifty eight rhizobacterial isolates were isolated (Ahmad et al., 2008). The rhizobacterial isolates were characterized on the basis of cultural, morphological and biochemical characteristics (Cappuccino and Sherman, 1992).

\section{Screening of soil bacterial strains for plant growth promoting activities}

\section{Indole acetic acid production}

The IAA production was assayed by the modified method as described by Loper and Scroth (1986). Bacterial cultures were grown for $48 \mathrm{~h}$ (Pseudomonas, Bacillus), and $72 \mathrm{~h}$ (Azotobacter) on their respective media at $28^{\circ} \mathrm{C}$ on rotary shaker. Fully grown cultures were centrifuged at $10000 \mathrm{rpm}$ for $15 \mathrm{~min}$. The $2 \mathrm{ml}$ of supernatant was mixed with 2 to 3 drops of O-phosphoric acid and $4 \mathrm{ml}$ of salkouski reagent solution $\left(1 \mathrm{ml}\right.$ of $\mathrm{FeCl}_{3} 0.5 \mathrm{M}$ mixed in 50 $\mathrm{ml}$ of $35 \% \mathrm{HClO}_{4}$ ). The samples were incubated for $25 \mathrm{~min}$ at room temperature. The development of pink color was observed and optical density was taken at $530 \mathrm{~nm}$ with help of spectrophotometer. The concentration of IAA produced by cultures was measured with the help of standard graph of IAA obtained in the range of 20 to $200 \mu \mathrm{g} \mathrm{ml}^{-1}$.

\section{Ammonia production}

The isolates were grown in peptone water in tubes incubated at $30^{\circ} \mathrm{C}$ for four days. One $\mathrm{ml}$ of Nessler's reagent $(0.09 \mathrm{~mol} / \mathrm{L}$ solution of potassium tetra-iodo-mercurate (II) in $2.5 \mathrm{~mol}$ potassium hydroxide was added in each test tube. The observed presence of faint yellow color indicates small amount of ammonia and deep yellow to brownish color indicates maximum production of ammonia (Cappuccino and Sherman, 1992).

\section{Phosphorus solubilization}

All the isolates were spot inoculated on Pikovskaya agar medium (Yeast extract $0.5 \mathrm{~g}$ Dextrose $10 \mathrm{~g}$, Calcium phosphate $5 \mathrm{~g}$, Ammonium sulphate $0.5 \mathrm{~g} \mathrm{KCl} 0.2 \mathrm{~g} \mathrm{Mg} \mathrm{SO} 40.1 \mathrm{~g} \mathrm{MnSO}_{4} 0.0001$ $\mathrm{g}$, FeSO4 $0.001 \mathrm{~g}$, Agar $15 \mathrm{~g}$ and $1 \mathrm{~L}$ distilled water) with phosphorus source and incubated at $28^{\circ} \mathrm{C}$ for 4 days. Phosphorus activity was determined by development of clearing zone around the culture spot (Agrawal et al., 2011; Wahyudi et al., 2011).

\section{Siderophore production}

Bacterial isolates were tested for siderophore production on chome azurol (60.5 mg CAS,1 Mm FeCl3.6H2O, $10 \mathrm{M} \mathrm{HCl}, 72.9 \mathrm{mg}$ HDTMA, $1 \mathrm{M}$ Sucrose $(3 \mathrm{ml}), 1 \mathrm{M} \mathrm{CaCl}_{2}(0.4 \mathrm{ml}), 1 \mathrm{M} \mathrm{MgSO}_{4} .7 \mathrm{H}_{2} \mathrm{O}$ $(0.8 \mathrm{ml}), 2 \% \mathrm{~K}_{2} \mathrm{HPO}_{4}\left(10 \mathrm{ml}, \mathrm{NaCl}(0.2 \mathrm{~g}), \mathrm{NaMoO}_{4}(0.005 \mathrm{~g})\right.$, PIPES (30.24 g), Difco agar (15 g), 10\% Casamino acid (30 ml)) ) s agar (CAS) medium described by Schwyn and Neilands (1987). Each isolate was streaked on surface of CAS agar medium and incubated at room temperature for 1 to 2 days. The development of orange halo around the growth has been considered as positive for siderophore production.

\section{Antibiotic sensitivity}

The isolates were tested against the tetracycline by agar dilution method as described by Ahmad et al. (2004). The stock solution (5 $\mathrm{mg} / \mathrm{ml}$ ) of antibiotic, that is, tetracycline has prepared and used four different concentrations $1,5,10$ and $20 \mu \mathrm{g} / \mathrm{ml}$ for antibiotic sensitivity test. The tetracycline was dissolved in $70 \%$ ethanol and sterilized with membrane filler (Axiva Scihem biotech). The nutrient agar medium was prepared in $4 \mathrm{~L}$ flasks of $500 \mathrm{ml}$ and allowed to cool to $50^{\circ} \mathrm{C}$. The diluted tetracycline of different concentrations were mixed in cool molten agar medium and poured in petri plates. The isolates were spot inoculated on solidified agar plate and incubated at $30^{\circ} \mathrm{C}$ for $48 \mathrm{~h}$. After incubation, the plates were examined for the presence or absence of growth on the spotted area. The strains which were sensitive against tetracycline did not grow on the plate and resistant strains shows the growth on the plates against tetracycline.

\section{Salt tolerance}

The pure cultures of all isolates were streaked on nutrient agar medium, containing 3 to $7 \% \mathrm{NaCl}$ concentration. Control plates with $\mathrm{NaCl}$ amendment were also kept for observation for all strains. All plates were incubated at $30^{\circ} \mathrm{C}$ for $48 \mathrm{~h}$ and observed for the presence or absence of the growth.

\section{RESULTS AND DISCUSSION}

\section{Isolation and biochemical characterization}

On the basis of cultural, morphological and biochemical characteristics a total of 58 bacterial isolates were identified as Azotobacter, Pseudomonas and Bacillus as described in Bergeys manual of determinative bacteriology (Holt et al., 1994). The Azotobacter, Pseudomonas and Bacillus strains from rhizosphere of different crops were isolated and extensively studied by Kole and Hajra (1997), Gaind and Gaur (1999), Ahmad et al. (2005), Joseph et al. (2007), Fischer et al. (2007), Ahmad et al. (2008), and Wahyudi et al. (2011). The general characteristics of the isolates were illustrated (Table 1).

\section{Screening of rhizobacteria for plant growth promoting traits}

In the present study a total of 58 bacterial strains (22 isolates of Pseudomonas and 18 of each Azotobacter and Bacillus) were tested for IAA, ammonia production, phosphorus solubilization and siderophore production (Figure 1). IAA production was shown in most of the Pseudomonas isolates (86.36\%) followed by Azotobacter (76.19\%) and Bacillus (38.09\%). Ammonia production was detected in $90.89 \%$ of Pseudomonas followed by Bacillus (76.19\%) and Azotobacter (66.43). The Azotobacter (66.23\%), Pseudomonas (45.35\%) and Bacillus (23.80\%) strains were found able to solubilize phosphate. Very few strains of Azotobacter (20.17\%), Pseudomonas (13.46\%) and Bacillus (9.61\%) exhibited siderophore production. Similar to our findings of plant growth promoting activities among Rhizobacteria strains have also been reported by some other workers 
Table 1. Morphological and cultural characteristic of rhizobacterial test isolates.

\begin{tabular}{|c|c|c|c|c|}
\hline $\begin{array}{l}\text { Biochemical } \\
\text { characters }\end{array}$ & Azotobacter spp. & Pseudomonas spp & Bacillus spp & \\
\hline Number of isolates & 18 & 22 & 18 & \\
\hline Grams reaction & -ve & -ve & + ve & \\
\hline Shape & rods & rods & rod & \\
\hline Pigment & $\begin{array}{l}\text { Transparent to light milky most } \\
\text { isolates become light brown to black } \\
\text { after } 10 \text { days of incubation }\end{array}$ & Cream, light to green & Cream & \\
\hline Colony morphology & $\begin{array}{l}\text { Watery mucilaginous with smooth } \\
\text { margins }\end{array}$ & Smooth margin, flat to raised & $\begin{array}{l}\text { Circular, lobate } \\
\text { serrated margin }\end{array}$ & to \\
\hline Sucrose & + & + & + & \\
\hline Dextrose & + & + & + & \\
\hline Mannitol & + & - & + & \\
\hline $\mathrm{H}_{2} \mathrm{~S}$ production & - & - & - & \\
\hline Indole & - & - & - & \\
\hline Methyl red & - & - & - & \\
\hline Vogues Prokauer & - & - & - & \\
\hline Citrate Utilization & + & + & + & \\
\hline Starch & + & + & + & \\
\hline Gelatin hydrolysis & - & + & - & \\
\hline Catalase test & + & + & + & \\
\hline Nitrate reduction & - & + & - & \\
\hline Lipid hydrolysis & + & + & + & \\
\hline Casein hydrolysis & + & + & + & \\
\hline
\end{tabular}

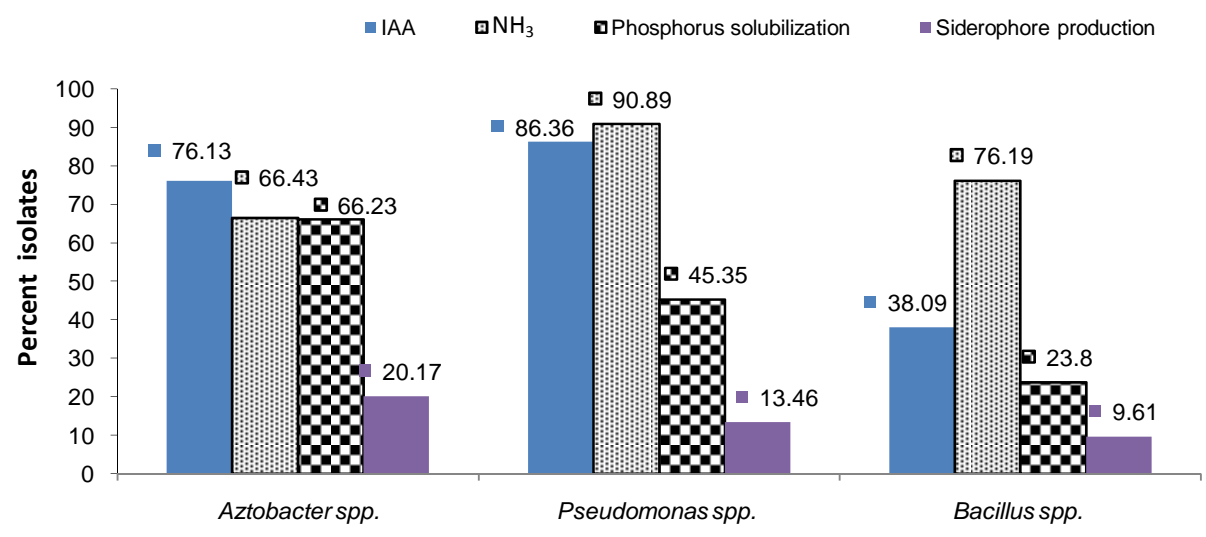

Figure 1. Plant growth promoting activities of rhizobacterial test isolate.

(Corsa and Walsh, 2002; Huddedaret al., 2002; Ahmad et al., 2004; Pedraza et al., 2004; Ahmad et al., 2008; Sachdev et al., 2009; Joshi and Bhatt, 2011; Rawat and Asrar, 2011).

\section{Quantitative screening for IAA production by selected rhizobacterial isolates}

Total of 18 selected rhizobacterial isolates of
Pseudomonas (nine), Azotobacter (six) and Bacillus (three) were tested for quantitative IAA production. The production of IAA was recorded highest in isolates of Azotobacter, followed by Pseudomonas and Bacillus respectively. Among Azotobacter isolates, Azt-4 and Azt7 produced highest amount $(175.20 \mu \mathrm{g} / \mathrm{ml})$ of IAA followed by Azt-1>Azt3 >Azt-6. However, Pseudomonas rhizobacteria isolates produced IAA in the range of 44.40 to $95.60 \mu \mathrm{g} / \mathrm{ml}$ in the broth culture medium (Tables 2 and 3). Wahyudi et al. (2011) reported that Bacillus spp. Cr4 
Table 2. Production of Indole Acetic acid (IAA) by selected rhizobacterial isolates grown in respective medium.

\begin{tabular}{ccc}
\hline S/N & Isolate & IAA Production $\boldsymbol{\mu g} / \mathbf{m l}$ \\
\hline 1 & Azt1 & 130.15 \\
2 & Azt2 & 114.66 \\
3 & Azt3 & 114.66 \\
4 & Azt4 & 175.20 \\
5 & Azt5 & 95.60 \\
6 & Azt6 & 114.60 \\
7 & Azt7 & 175.20 \\
8 & Azt8 & 114.60 \\
9 & Azt9 & 114.60 \\
10 & Ps1 & 95.60 \\
11 & Ps2 & 79.60 \\
12 & Ps3 & 44.40 \\
13 & Ps4 & 66.20 \\
14 & Ps5 & 79.60 \\
15 & Ps6 & 79.60 \\
16 & Bc1 & 70.00 \\
17 & Bc2 & 72.40 \\
18 & Bc3 & 64.00 \\
& CD & 22.08 \\
& SEm & 7.68 \\
\hline
\end{tabular}

Table 3. Antibiotic sensitivity and salt tolerance of selected rhizobacterial test isolates.

\begin{tabular}{|c|c|c|c|c|c|c|c|c|c|c|}
\hline \multirow{2}{*}{$\mathrm{S} / \mathrm{N}$} & \multirow{2}{*}{ Isolate } & \multicolumn{4}{|c|}{ Antibiotic concentration $(\mu \mathrm{g} / \mathrm{ml})$} & \multicolumn{5}{|c|}{$\mathrm{NaCl}$ concentration (\%) } \\
\hline & & 1 & 5 & 10 & 20 & 3 & 4 & 5 & 6 & 7 \\
\hline 1 & Azt1 & ++ & ++ & - & - & ++ & - & - & - & - \\
\hline 2 & Azt2 & +++ & - & - & - & ++ & - & - & - & - \\
\hline 3 & Azt3 & ++ & + & - & - & + & - & - & - & - \\
\hline 4 & Azt4 & +++ & - & - & - & - & - & - & - & - \\
\hline 5 & Azt5 & +++ & +++ & ++ & - & +++ & ++ & + & + & - \\
\hline 6 & Azt6 & - & - & - & - & ++ & - & - & - & - \\
\hline 7 & Azt7 & ++ & ++ & - & - & ++ & + & - & - & - \\
\hline 8 & Azt8 & +++ & - & - & - & ++ & + & - & - & - \\
\hline 9 & Azt9 & +++ & +++ & ++ & ++ & + & + & + & - & - \\
\hline 10 & Ps1 & +++ & - & - & - & - & - & - & - & - \\
\hline 11 & Ps2 & +++ & +++ & +++ & ++ & + & + & - & - & - \\
\hline 12 & Ps3 & ++ & ++ & - & - & + & + & - & - & - \\
\hline 13 & Ps4 & +++ & - & - & - & + & + & - & - & - \\
\hline 14 & Ps5 & +++ & +++ & - & - & + & - & - & - & - \\
\hline 15 & Ps6 & ++ & ++ & ++ & - & + & - & - & - & - \\
\hline 16 & $\mathrm{Bc1}$ & +++ & ++ & - & - & +++ & +++ & +++ & +++ & + \\
\hline 17 & $\mathrm{Bc} 2$ & +++ & +++ & +++ & +++ & +++ & + & - & - & - \\
\hline 18 & $\mathrm{Bc} 3$ & +++ & +++ & ++ & - & +++ & +++ & ++ & ++ & + \\
\hline
\end{tabular}

Azt $=$ Azotobacter, $\mathrm{Ps}=$ Pseudomonas, $\mathrm{Bc}=$ Bacillus, Incubation period $36 \mathrm{~h} ;+++=$ maximum growth, $++=$ medium growth, + poor growth, - = no growth.

produced $86.82 \mathrm{mg} / \mathrm{L} \quad \mathrm{IAA}$ in culture medium supplemented with L Tryptophan while $32.80 \mu \mathrm{g} / \mathrm{ml} \mathrm{IAA}$ production was reported by Ahmad et al. (2004). The findings of present investigation are outstanding in 
reference to earlier reports.

\section{Salt tolerance and antibiotic sensitivity test}

The present study showed that out of 18 selected strains, Azt-5, Bc-2 and bc-3 tolerated even $7 \% \mathrm{NaCl}$ concentration. All the rhizobacterial strains were found tolerant at $3 \% \mathrm{NaCl}$ concentration except Azt4 and Ps-1 (Table 3). Rangarajan et al. (2002) screened Pseudomonas strains for salt tolerance; out of 256 strains, only 36 strains could grow at $4.5 \% \mathrm{NaCl}$ concentration and no strain was able to grow at $6 \% \mathrm{NaCl}$ concentration. Similarly, the selected strains were also tested against the tetracycline. The isolate Azt-9Ps-2 and $\mathrm{Bc} 2$ were found resistant even at the concentration of 20 $\mu \mathrm{g} / \mathrm{ml}$ of antibiotic while Azt6 showed very high sensitivity against the test antibiotic and could not tolerate even 1 $\mu \mathrm{g} / \mathrm{ml}$ concentration.

\section{Conflict of Interest}

The author(s) have not declared any conflict of interests.

\section{REFERENCES}

Agrawal PK, Agrawal S, Singh SK, Kumar S, Shukla KP (2011). Characterization of Plant Growth Promoting Bacteria From Soil Of Central and Upper Himalayan Region., IJABPT 2(1):363-369.

Agrios GN(2005). Plant Pathology. Amsterdam: Academic. pp.635.

Ahmad I, Sharma J, Ahmad F (2004). Isolation and Characterization of Resistance Traits of Indigenous Strains of Acetobacter diazotrophicus Associated with sugarcanes. Sugar Tech. 6(1\&2):4146. http://dx.doi.org/10.1007/BF02942616

Ahmad F, Ahmad I, Khan MS (2005). Indole Acetic Acid Production by the Indigenous Isolates of Azotobacter and Fluorescent Pseudomonas in the Presence and Absence of Tryptophan. Turk. J. Biol. 29:29-34.

Ahmad F, Ahmad I, Khan M.S (2008). Screening of free living rhizospheric bacteria for their multiple plant growth promoting activites.

Bais HP, Weir TL, Perry LG, Gilroy S, Vivanco1 JM (2006). The role of root exudates in rhizosphere interactions with plants and other organisms. Annu. Rev. Plant Biol. 57:233-266. http://dx.doi.org/10.1146/annurev.arplant.57.032905.105159 PMid: 16669762

Bent E, Tuzun S, Chanway CP, Enebak S (2001). Alterations in plant growth and in root hormone levels of lodgepole pines inoculated with rhizobacteria. Can. J. Microbial. 47:793-800. http://dx.doi.org/10.1139/w01-080 PMid: 11683460

Cappuccino, JC, Sherman N (1992). In Microbiology: A laboratory Mannual, third ed. Benjamin cummings Pub. Co.,m New York, pp. 125-179.

Corsa JH, Walsh CT (2002). Genetic and assembly line enzymology of siderophore biosynthesis in bacteria. Microbiol. Mol. Bio. Rev. 66(2):223-249. http://dx.doi.org/10.1128/MMBR.66.2.223-249.2002 PMCid:PMC120789

Dilfuza E (2005). Characterization of Pseudomonas Species Isolated from the Rhizosphere of Plants Grown in Serozem Soil, Semi-Arid Region of Uzbekistan. The Scientific World Journal 5: 501-509. http://dx.doi.org/10.1100/tsw.2005.64 PMid:16075145

Duffy BK, Ownley BH, Weller DM (1997). Soil chemical and physical properties associated with suppression of take-all of wheat by
Trichoderma koningii. Phytopathology 87:1118-1124. http://dx.doi.org/10.1094/PHYTO.1997.87.11.1118 PMid:18945008

Etesami H, Hossein AA, Abolfazl AA (2009). Evaluation of Plant Growth Hormones Production (IAA) Ability by Iranian Soils Rhizobial Strains and Effects of Superior Strains Application on Wheat Growth Indexes. World Appl. Sci. J. 6(11):1576-1584.

Fischer SE, Fischer SI Magris S Mori GB (2007). Isolation and characterization of bacteria from the rhizosphere of wheat. World $\mathrm{J}$. Microb. Biotechnol. 23:895-903. http://dx.doi.org/10.1007/s11274006-9312-4

Flores-Fargas RD, O'Hara GW (2006). Isolation and characterization of rhizosphere bacteria with potential for biological control of weeds in vineyards. J. Appl. Microbiol. 100:946-954 http://dx.doi.org/10.1111/j.1365-2672.2006.02851.x PMid:16629995

Gaind S, Gaur AC (1999). Microbial phosphate solubilization as influenced by sodium chloride. Indian J. Exptl. Biol. 37:209-210.

Glick BR (1995). The enhancement of plant growth by free-living bacteria. Can. J. Microbiol. 41:109-117. http://dx.doi.org/10.1139/m95-015

Glick BR, Bashan Y(1997). Genetic manipulation of plant growthpromoting bacteria to enhance biocontrol of phytopathogens. Biotechnol. Adv. 15:353-378. http://dx.doi.org/10.1016/S07349750(97)00004-9

Holt JG, Krieg NR, Sneath PAP (1994).Bergeys Manual of Determinative Bacteriology. 9th Ed, Willium and Wilkins Pub, Baltimore.

Huddedar SB, Gore SD, Chopade BA (2000). Studies on distribution and characterization of Acinetobacter genospecies isolated from rhizosphere of wheat exhibiting antifungal and antibacterial activity. In: Proceedings of International Conference on Microbial Biotechnology, Trade and Public Policy, Hyderabad, India. pp. 1-16.

Huddedar SB, Shete AM, Tilekar JN, Gore SD, Dhavale, DD, Chopade BA (2002). Isolation, characterization and plasmid pUPI126 mediated indole-3-acetic acid production in Acinetobacter strains from rhizosphere of wheat. Appl. Biochem. Biotech. 102-103:21-29. http://dx.doi.org/10.1385/ABAB:102-103:1-6:021

Joshi $P$, Bhatt $A B$ (2011). Diversity and function of plant growth promoting Rhizobacteria associated with wheat Rhizosphere in North Himalayan Region. Int. J. Environ. Sci. 1(6):1135-1143.

Johnsson L, Hokeberg M, Gerhardson B (1998). Performance of the Pseudomonas chlororaphis biocontrol agent MA 342 against cereal seedborne diseases in field experiments. Eur. J. Plant Pathol 104:701-711. http://dx.doi.org/10.1023/A:1008632102747

Joseph B, Patra RR, Lawrence R (2007). Characterization of plant growth promoting rhizobacteria associated with chickpea (cicer arietinum-L). Int. J. Plant Prot. 1(2).

Kloepper JW, Lifshitz R, Zablotowicz RM (1989). Free living bacterial inocula for enhancing crop productivti. Trends Biotechnol. 7:3943.http://dx.doi.org/10.1016/0167-7799(89)90057-7

Kole SC, Hajra, JN (1997). Occurrence and acidity of tricalcium phosphate and rock phosphate solubilizing microorganisms in mechanical compost plantsof Calcutta and alluvial soil of west Bengal. Environ. Ecol. 16(2):344-349.

Lægreid M, Bøckman OC, Kaarstad O (1999). World cereal productionchallenges and opportunities. In: Agriculture, fertilizers and environment. CABI publishing in association with Norsk Hydro ASA, UK, pp. 219-234.

Loper JE, Scroth MN (1986). Inflence of bacterial sources on Indole 3 acetic acid on root elongation of sugarbeet. Phytopathology $76: 386$ 389 http://dx.doi.org/10.1094/Phyto-76-386

Pedraza, RO, Xiqui MA, Baca BE (2004). Aromatic amino acid aminotransferase activity and indole -3 acetic acid production by associative nitrogen fixing bacteria. FEMS. Microbiol. Lett. 233(1):1521.http://dx.doi.org/10.1016/j.femsle.2004.01.047 PMid:15043864

Rangarajan S, Saleena, LM, Nair S (2002). Diversity of pseudomonads isolated from rice rhizospheres populations grown along a salinity $\begin{array}{llll}\text { gradient. J. } & \text { Jppl. } & \text { Microbiol. } & \text { 91:742-749. }\end{array}$ http://dx.doi.org/10.1046/j.1365-2672.2001.01442.x

Rawat S, Asrar I (2011). Bacterial Diversity in Wheat Rhizosphere and their Characterization. Adv. Appl. Sci. Res. 2(2):351-356.

Sachdev DP, Chandhari HG, Kasture VM, Dhavale DD, Chopade BA (2009). Isolation and characterization of indole acetic acid (IAA) 
producing Klebsiella pseumoniae strains from rhizosphere of wheat (Triticum aestivum) and their effect on plant growth. Internet J. Microbiol. 47:993-1000.

Schwyn B, Neilands JB (1987). Universal chemical assy for the detection and determination of siderophore. Anal Biochem. 160:4756. http://dx.doi.org/10.1016/0003-2697(87)90612-9

Stark C, Condron LM, Stewart A, Di HJ, O'Callaghan M (2007). Influence of organic and mineral amendments on microbial soil properties and processes. Appl. Soil Ecol. 35:7993. http://dx.doi.org/10.1016/j.apsoil.2006.05.001

Valverde A, Igual JM, carvantes E (2003). Polyphasic characterization of phosphate-solublizing bacteria isolated from rhizospheric soil of the north-eastern region of Portugal. Cordel de merinas, pp. 40-52.
Wahyudi AT, Rina PA, Asri W, Anja M, Abdjad AN (2011). Characterization of Bacillus sp. strains isolated from rhizosphere of soybean plants for their use as potential plant growth for promoting Rhizobacteria. J. Microbiol. Antimicrob. 3(2):34-40. 